\title{
Cellular Components of Subretinal Membranes in Proliferative Vitreoretinopathy
}

\author{
P. HISCOTT, I. MORINO, R. ALEXANDER, I. GRIERSON, Z. GREGOR \\ London
}

\begin{abstract}
Summary
To determine the cellular composition of subretinal membranes in proliferative vitreoretinopathy, surgically excised membranes were studied using electron microscopic and immunohistochemical procedures. Light microscopic immunohistochemistry was found to be superior to conventional electron microscopy as a means of evaluating the relative contributions of retinal pigment epithelium and glia to subretinal membranes. The cells of subretinal membranes chiefly comprised retinal pigment epithelium while glial cells were either absent or contributed only a minor component. It is proposed that the clinical properties of subretinal membranes in proliferative vitreoretinopathy derive from their retinal pigment epithelial cell element.
\end{abstract}

During surgery for proliferative vitreoretinopathy (PVR), retinal reattachment may be prevented by taut, fibrocellular bands beneath the human sensory retina ('subretinal membranes'-SRMs). Such tensile SRMs are the subjects of several structural and ultrastructural reports ${ }^{1-8}$, but their cellular origins remain unclear. Retinal pigment epithelium (RPE)—including metaplastic ('activated') forms - and glia are among the cells reported in SRMs of PVR, but it is difficult to differentiate between metaplastic RPE and glial cells by electron microscopy ${ }^{9}$. Moreover, ultrastructural analysis has inherent limitations on tissue sampling so that the cells studied may not be representative of the SRM as a whole.

Conversely, immunohistochemical procedures permit more reliable detection of metaplastic retinal pigment epithelial and glial cells in pathological tissues than do ultra- structural methods. ${ }^{10,11}$. Therefore, we have evaluated, and subsequently employed, electron microscopy and light microscopic immunohistochemistry as means of determining the nature and distribution of the cellular components in SRMs of PVR. Our preliminary findings, involving surgically excised PVR SRMs, are the subject of this report.

\section{Materials and Methods}

Subretinal membranes (which had arisen following rhegmatogenous retinal detachment) were obtained from nine eyes during closed pars-plana microsurgery. Two SRMs were studied by transmission electron microscopy and the remaining seven specimens processed for immunohistochemical analysis.

\section{Transmission Electron Microscopy}

The SRMs were fixed in $3 \%$ buffered glu-

From: The Department of Pathology, Institute of Ophthalmology, London and Moorfields Eye Hospital, London.

Correspondence to: Paul Hiscott PhD FRCS, Department of Pathology, Institute of Opthalmology, 17-25, Cayton St., London EC1V 9AT. 


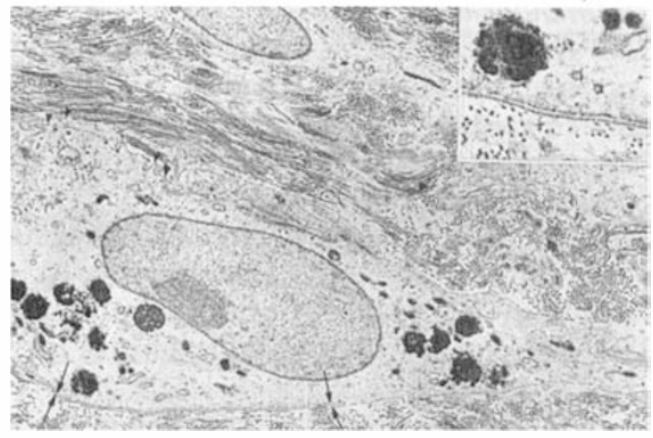

Fig. 1. A transmission electron micrograph of an excised subretinal membrane. A cell exhibiting basement membrane material (arrows) and microvillouslike structures (arrowheads) is present in the tissue ( $\times 5000)$. Inset Higher power micrograph of the basement membrane material adjacent to the cell surface $(\times 15000)$.

taraldehyde, processed for transmission electron microscopy ${ }^{11}$ as previously described and examined in a Jeol 100C electron microscope.

\section{Immunohistochemistry}

Specimens were fixed in $10 \%$ formol-saline, dehydrated in graded alcohol and embedded in paraffin wax. Sections $5 \mu \mathrm{m}$ thick of waxembedded tissue were immunostained for (i) cytokeratin (an epithelial cell marker) (ii) glial fibrillary acidic protein (GFAP - a glial cell marker) as previously described ${ }^{10,11}$. Because the cytokeratins (chiefly comprising types 8 and $18^{12,13}$ ) expressed by RPE cells may vary, we employed antisera with a wide spectrum of immunoreactivity (as opposed to monoclonal antibodies which react with only one or a few cytokeratin subtypes) in order to minimise false-negative staining. The antisera to both cytokeratins and GFAP were raised in rabbits. The immunoperoxidase technique (based on either the peroxidase-antiperoxidase or the labelled avidin-biotin method of Giorno $^{14}$ ) was used throughout this investigation. To facilitate the evaluation of immunostaining in pigmented tissues, we used the peroxidase substrate 3-amino-9-ethylcarbazole (AEC) which yielded a pink/red reaction product. Some sections were counterstained with Mayer's haematoxylin. Appropriate controls were applied to all procedures $^{10,11}$. The preparations were examined by light and differential interference contrast microscopy, and the percentage of cells staining positively for cytokeratin or GFAP was recorded (this semiquantitative assessment was made by three observers independently and the results subsequently averaged).

\section{Results}

\section{Transmission Electron Microscopy}

One of the specimens processed for ultrastructural evaluation contained elongated cells set in extracellular fibrous material. Some of the cells were associated with basement membrane-like material and microvillous-like structures, and contained pigment and lipid inclusions (Fig. 1). The intermediate filaments of most cells were scattered within their cytoplasm (rather than arranged as prominent bundles). The second specimen
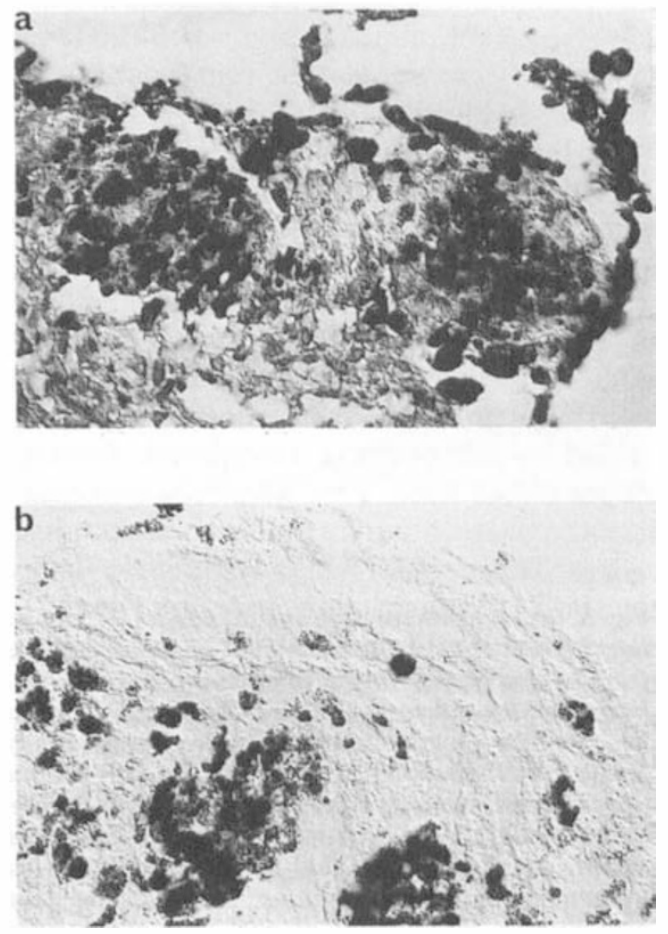

Fig. 2. Differential interference contrast micrographs of a subretinal membrane: (a) stained with the immunoperoxidase technique for cytokeratins (no counterstain). The vast majority of the cells are cytokeratinpositive $(\times 300)$. (b) Control section as in $(a)$ in which the primary antibody has been replaced by an inappropriate antibody. No reaction product is visible. The cells contain variable amounts of melanin $(\times 300)$. 

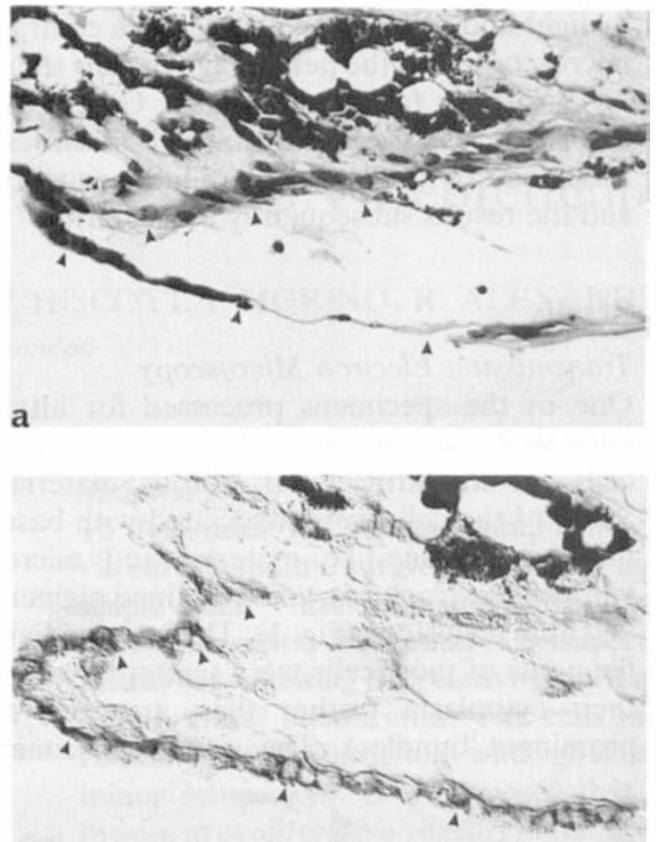

b

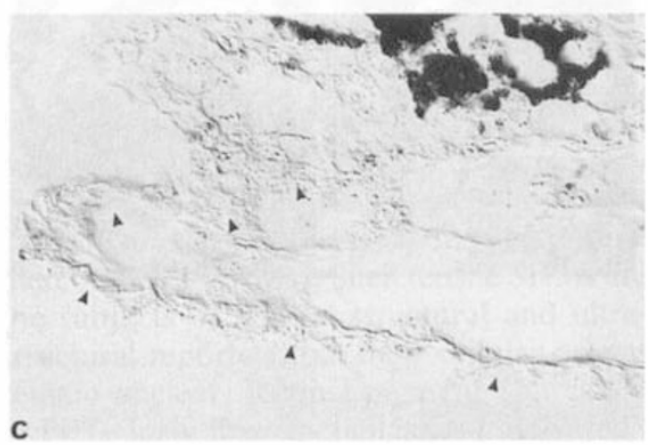

Fig. 3. (a) Light micrograph and (b) and (c) differential interference contrast micrographs of serial sections from a subretinal membrane. (a) Staining with haematoxylin and eosin reveals the presence of prominent cellular layers in the specimen (arrowheads; $\times 450$ ). (b) Immunolabelling for cytokeratins (immunoperoxidase method; no counterstain) shows that the cells in the layers are cytokeratin-positive (arrowheads; $\times 450$ ). (c) Staining for glial fibrillary acidic protein (immunoperoxidase technique; no counterstain) demonstrates the absence of glial cells in the tissue (arrowheads indicate cell layer; $\times 450$ ).

chiefly comprised cells (of indeterminate origin) which exhibited marked lipoidal degeneration in fibrin-like extracellular material.

\section{Immunohistochemistry}

All seven of the SRMs contained cytokeratinpositive cells (Figs. 2a, b and 3a, b). The estimated epithelial cell component ranged from approximately $50 \%$ to $90 \%$ (Table). The epithelial cells were arranged in layers (seven specimens) together with foci of aggregated cells (three specimens) (Table; Fig 3a, b). In addition, isolated cytokeratin-positive cells were observed in extracellular fibrous tissue (three specimens). Epithelial cells in layers and foci were rounded or cuboidal in shape, while isolated cells were often spindleshaped.

Five of the seven SRMs also exhibited GFAP-positive cells and in these specimens the glial cells represented approximately 5\% to $15 \%$ of the cells in the SRMs (Table; Figs 3c and $4 a, b)$. Glial cells were usually seen in isolation, often at the margins of the specimens, but occasional foci or layers comprising several GFAP-positive cells were observed in three SRMs. (Table; Fig 4a, b).

Cells which failed to stain for either cytokeratin or GFAP (detected by examining serial sections from the membranes) were rare. Capillaries (undetected clinically) were found in one specimen.

\section{Discussion}

Although some of the cells expressed features consistent with RPE cells in one SRM subjected to ultrastructural evaluation, many cells lacked the morphological features of RPE or glial cells. This observation underlines the inadequacy of electron microscopy as a means of identifying the origins of 'activated' cells in SRMs. The derivation of metaplastic cells in SRMs has been investigated by in vitro studies ${ }^{15,16}$, but tissue culture methods have been shown selectively to favour the outgrowth (and, therefore, identification) of some cell types more than others from 'explants' of PVR specimens ${ }^{17}$. Conversely, we have been able to identify metaplastic RPE and glial cells in PVR specimens by the immunohistochemical procedures described in this, and previous ${ }^{10,11}$, investigations. Moreover, light microscopic immunochemistry on multiplesections allowed more representative tissue sampling than electron microscopic or in vitro analysis and, therefore, the contri- 
Table Immunohistochemistry of seven excised subretinal membranes

\begin{tabular}{cclcl}
\hline Specimen no. & $\begin{array}{c}\text { \% cells cytokeratin } \\
\text { positive }\end{array}$ & $\begin{array}{c}\text { Distribution of } \\
\text { epithelial component }\end{array}$ & $\begin{array}{c}\text { \% cells GFAP } \\
\text { positive }\end{array}$ & $\begin{array}{c}\text { Distribution of } \\
\text { glial component }\end{array}$ \\
\hline 1 & 95 & Layers & 0 & - \\
$2^{*}$ & 65 & Layers & 10 & Layers \\
3 & 80 & Layers/foci/diffuse & 10 & Diffuse \\
4 & 50 & Layers/diffuse & 15 & Layers/diffuse \\
5 & 90 & Layers & 10 & Foci/diffuse \\
6 & 80 & Layers/foci & 0 & Diffuse \\
\hline
\end{tabular}

Key: * Specimen contained capillaries.

bution of RPE and glial cells to PVR SRMs could be assessed.

Our findings confirm the presence of RPE and glial cells in human SRMs. Moreover, our semiquantitative evaluation of immunohistochemical results demonstrates that the vast majority of cells in PVR SRMs are derived from RPE. On the other hand, the
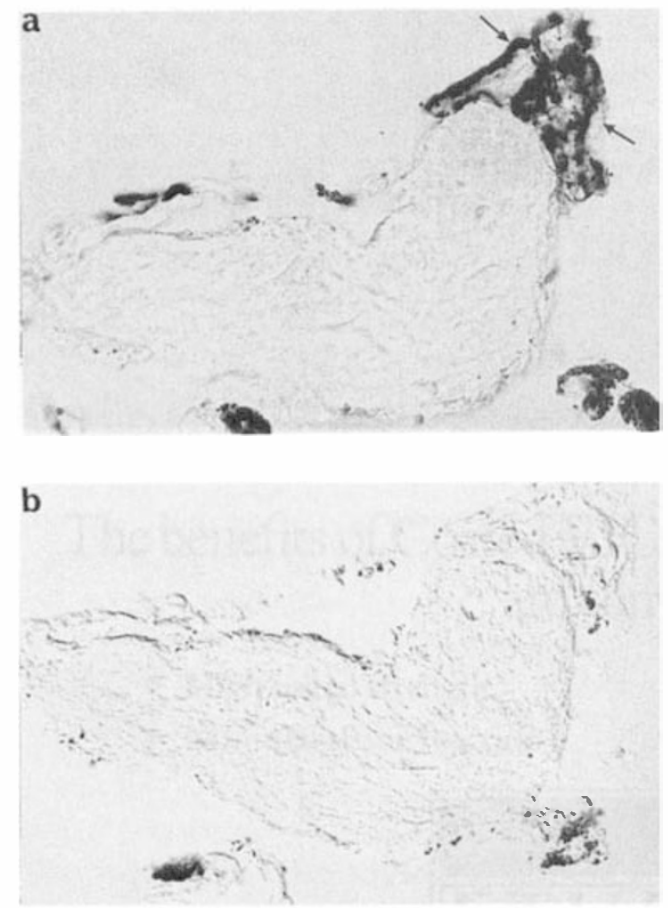

Fig. 4. Differential interference contrast micrographs of a subretinal membrane stained with the immunoperoxidase technique (no counterstain). (a) Immunostained for glial fibrillary acidic protein. A focus of glial cells is apparent in the specimen (arrows; $\times 300)$. (b) A serial section as in (a) but excluding the primary antibody $(\times 300)$. glial component appears to be restricted to a few isolated cells or is even absent altogether. Thus, although the types of cells found in surgically excised SRMs are similar to those found in contractile membranes on the retinal surface $^{4}$ (epiretinal membranes), the contribution of the various cell types found in SRMs differs markedly from that found in epiretinal proliferations. For example, PVR epiretinal membranes may contain few or even no RPE cells while non-epithelial fibroblast-like cells may comprise the bulk of the epiretinal cells ${ }^{10}$. Moreover, epiretinal membranes contain a more conspicuous glial component (where layers of GFAP-positive cells often are prominent $^{11}$ ) compared to SRMs.

Nevertheless, SRMs comprised purely of glial cells occur in PVR, but they tend to form thin, non-fibrous sheets which neither cause retinal detachment nor prevent retinal reattachment in $\operatorname{man}^{5,7,18,19}$. Such SRMs are the subretinal correlate of pure, asymptomatic glial proliferations on the retinal surface ("simple epiretinal membranes" ${ }^{20}$ ). However, whereas epiretinal glial proliferation may also have an important role in the pathobiology of contractile epiretinal membranes ${ }^{11}$, the relative infrequency or absence of glia in problematic subretinal bands suggests they are only incidently involved in, and lack a major role in the clinical bahaviour of, tensile SRMs. Thus, the SRMs which require surgical intervention in PVR probably owe their clinical import to their RPE cell content.

Financial support was provided by the Wellcome Trust (grant no. 17095/1.4), T.F.C. Frost foundation and Fight for Sight. 


\section{References}

${ }^{1}$ Winthrop SR, Cleary PE, Minckler DS, Ryan SJ: Penetrating eye injuries: a histopathological review. Br J Ophthalmol 1980, 64: 809-17.

${ }^{2}$ Trese MT, Chandler D, Machemer R, Charles S: Symptomatic sub-retinal strands ultrastructure and cell behaviour. AVRO abstracts 1983, 24: 291.

${ }^{3}$ Federman JL, Foldberg R, Ridley M, Arbizo VA: Subretinal cellular bands. Trans Am Ophthalmol Soc 1983, 81: 172-9.

${ }^{4}$ Daicker B: Constricting retroretinal membranes associated with traumatic retinal detachments. Graefe's Arch Clin Exp Ophthalmol 1985, 222: 147-53.

${ }^{5}$ Trese MT, Chandler DB, Machemer R: Subretinal strands: Ultrastructural features. Graefe's Arch Clin Exp Ophthalmol 1985, 223, 35-40.

${ }^{6}$ Morino I, Kazusa R, Yamanaka A: Glial cells in subretinal strand. J New Ophthalmol (Atarashii Ganka) 1987, 4: 279-82.

${ }^{7}$ Wilkes SR, Mansour AM, Green WR: Proliferative vitreoretinopathy histopathology of retroretinal membranes. Retina 1987, 7: 94-101.

${ }^{8}$ Bornfield N, El-Hifnawi E, Laqua H: Ultrastructure of subretinal membranes in PVR. International Symposium on PVR 1988, 4.8.

${ }^{9}$ Kampik A. Kenyon KR, Michels RG, Green WR, de la Cruz ZC: Epiretinal and vitreous membranes comparative study of 56. cases. Arch Ophthalmol 1981, 99: 1445-54.

${ }^{10}$ Hiscott PS, Grierson I, McLeod D: Retinal pigment epithelial cells in epiretinal membranes: an immunohistochemical study. $\mathrm{Br} \mathrm{J}$ Ophthalmol 1984, 68: 708-15.

${ }^{11}$ Hiscott PS, Grierson I, Trombetta CJ, Rahi AHS, Marshall J, McLeod D: Retinal and epiretinal glia-an immunohistochemical study. $B r \quad J$ Ophthalmol 1984, 68: 698-707.

${ }^{12}$ McKechnie NM, Boulton M, Robey HL, Savage FJ, Grierson I: The cytoskeletal elements of human retinal pigment epithelium: in vitro and in vivo. $J$ Cell Sci 1988, 91: 303-12.

${ }^{13}$ Owaribe K, Kartenbeck J, Rungger-Brandle E, Franke WW: Cytoskeletons of retinal pigment epithelial cells: interspecies differences of expression patterns indicate independence of cell function from the specific complement of cytoskeletal proteins. Cell Tissue Res 1988, 254: 301-15.

${ }^{14}$ Giorno R: A comparison of two immunoperoxidase staining methods based on the avidin-biotin interaction. Diag Immunol 1984, 2: 161-6.

${ }^{15}$ Shirakawa H, Yoshimura N, Yakakawa R, Matsumura M, Okada M, Ogino N, Ogina N: Cell components in proliferative vitreoretinopathy: Immunofluorescent double staining of cultured cells from proliferative tissues. Ophthalmologica 1987, 194: 56-62.

${ }^{16}$ Matsumura M, Yamakawa R, Yoshimura N, Shirakawa H, Okada M, Ogino N: Subretinal Strands Tissue culture and histological study. Graefe's Arch Clin Exp Ophthalmol 1987, 225: 341-5.

${ }^{17}$ Hiscott PS, Grierson I, Hitchins CA, Rahi AHS, McLeod D: Epiretinal membranes in vitro Trans Ophthalmol Soc UK 1983, 103: 89-102.

${ }^{18}$ Sternberg P and Machemer R: Subretinal proliferation. Am J Ophthalmol 1984, 98: 456-62.

${ }^{19}$ Machemer R: Discussion of presentation by Federman JL, Foldberg R, Ridley M, Arbizo VA. Subretinal cellular bands. Trans Ophthalmol Soc UK 1983, 81: 172-80.

${ }^{20}$ Foos RY: Vitreoretinal juncture-simple epiretinal membranes. Graefe's Arch Clin Exp Ophthalmol 1974, 189: 231-50. 